\title{
Graphical Approach to Assess Urban Quality: Mapping Walkability Based on the TOD-Standard
}

Graphical expression through mapping can be an essential tool to conduct urban analysis, capable of expressing contextual spatial distribution and providing complementary information to numerical analysis. Although urban analytics are central for most issues in cities, mobility and transportation have traditionally been disciplines very tightly related with quantitative analysis. Mobility in urban areas has become a central issue due to its high impact in environmental, social and economic concerns. Multiple studies consider that walking presents social, health, economic and environmental benefits as a short distance transportation mode. As pedestrian displacements are characterized by presenting great adherence, the features of the environment where they are performed is key to guarantee their success and promote their use. To be able to design appropriate walking city conditions, it is necessary to undergo extensive analysis of existing urban areas and their walkability impact. In order to illustrate this, this study takes as a basis the Transit Orientated Development Standard (TOD Standard), a scoring instrument defined by the Institute for Transportation and Development Policy (ITDP), to evaluate the area of Saint-Lazare multimodal station in Paris. The aim of this work is to compare its quantitative and graphical results through georeferenced mapping and TOD Standard score based numerical data, in order to identify the complementary information provided by the mapping. The conclusions display the importance of using graphical analysis to be able to spot singular spatial distributions and influencing relations within the urban environment, often imperceptible in numerical values.

\section{Keywords}

Graphical expression; Urban analysis; Spatial distribution; GIS; Walkability; TOD Standard.

\section{INTRODUCTION}

\subsection{Graphical expression as an analysis method}

Drawing is one of the most natural ways the human being has to express itself, to communicate and to record data. From Paleolithic parietal cave paintings or different types of ideograms, such as Egyptian hieroglyphs or Sumerian cuneiform, to the computationally enhanced Geographic Information Systems that our digital age offers, the human being has shown to rely on graphical expression.

Graphical representation has been used as an analytical system to unfold relationships or achieve general overviews of dispersed data. For instance, the work of the English physician John Snow (1813-1858) [Snow, 1855] shows the importance of locating data and relying on ground plans to display situations in order to be able to convey information. Snow traced the source of a cholera outbreak, in London, through the graphical representation of the deceased geolocation. In a similar line, the civil engineer Charles Joseph Minard maps of Napoleon Russian campaign of 1812-1814 [Robinson, 1967; Friendly 2002] show the possibility of combining graphs and mapping to gain a clearer panorama of relations and possible causation. Representation tools condition the way we see the world [Santamaria \& Martínez, 2016] and, therefore, the decisions we take involving this reality and its future.

Although maps and graphical data are not new in the toolset of our societies, current technologies seem to have allowed a new leap forward in this field by providing more available information and more powerful managing software. In the domain of mobility in general and walkability or TOD developments in particular, these technologies have often been claimed to be the opening 
of new possibilities in terms of analyzing current and future developments and confronting them with TOD objectives [Leslie et al., 2007; Ackerson, 2005]. In a great range of TOD focused studies, current Geographical Information Systems (GIS) software are used as a tool to organize data regarding their geolocation, intersect different information through spatial relations and, from there, extract quantitative results. The graphical data provided in the process is often disregarded as an inevitable step in the way of collecting the real core results.

\subsection{Walkability and the TOD}

Walking is also the most natural way of moving for the human being. Our body, our sensorial perception and our mind have evolved for millions of years based on this displacement system [Pozueta et al., 2009]. The first cities were designed to ensure its proper development, as European centers still show nowadays by providing appropriate environments for moving by foot and reachable destinations at strolling pace [Southworth, 2005]. Walking is also the most adherent of our current transportation systems [Mezoued, 2016], ensuring a close and rich relation with the environment. The introduction of transit systems, with different kinds of propulsion methods, enabled these walkable environments to create connections with further contexts [Parcerisa \& Rubert de Ventós, 2001]. However, the rise of the automobile age in the $20^{\text {th }}$ century, with its consequent suburban based planning tendencies [Ewing, 1994], brought a decay period for both walking and transit systems [Montgomery, 2013]. Walking faded away to offer open access to motor propelled systems and transit infrastructures were dismantled to give way to individual freedom formally translated into cars.

The 1973 oil crisis and 1979 energy crisis set under new considerations this energy-consuming moving system and sprawl based developments [Ewing, 1994]. However, the environmental concerns were only the firsts to arise regarding this model. Soon, social, health and economic issues were connected with these motor based environments [Jacobs, 1992]. Currently, multiple benefits have been claimed to be connected with walking [Southworth, 2005]: reduction of congestion, low environmental impact and conservation of energy without air and noise pollution [Newman \& Kenworthy, 1999]; it is a socially equitable transportation mode and tends to promote sociability [Leyden, 2003], as well as mental and physical health [Frank et al., 2003; Ewing et al., 2003; Pucher \& Dijkstra, 2003]. Nevertheless, the close relation that walking establishes with the environment tends to work both ways; its adherence also brings as a consequence the need of a welcoming environment to ensure its performance [Kaufmann, 2011; Gehl, 2001]. Consequently, the car focused settings tend to be perceived as unpleasant by pedestrians. Therefore, reversing the mobility habits and bringing back walking can be difficult in certain environments [Gehl, 2001].

The spreading of the suburban model and the sprawl based development raised great concerns, especially in the United States, regarding the results of the late developments [Ewing, 2008; Jacobs, 1992] and the possible future of the American Metropolis [Calthorpe, 1993]. Soon, social movements grew together with new urban concepts, such as New Urbanism, Traditional neighborhood Developments, Pedestrian Pockets, Urban Villages or Compact Communities, seeking to offer alternatives to current urban realities [Carlton, 2009]. Although different strategies were used, their ideas were centered in fostering walkable environments, slow mobility systems (walking, bicycle) and transit use through the design of new urban developments and the rehabilitation of existing ones.

It is in this context when the first Transit Oriented Development (TOD) concept appeared, introduced by Calthorpe in the 1980's and becoming a planning referent in the United States through "The New American Metropolis" [Calthorpe, 1993]. It has been defined as "a mixed-use 
community that encourages people to live near transit services and to decrease their dependence on driving" [Still, 2002].

The TOD Standard is a "tool to help shape and assess urban development. It focuses on maximizing the benefits of public transit and non-motorized mobility while placing the emphasis firmly back on the users: people" [ITDP, 2017]. This Standard is developed by the Institute for Transportation \& Development Policy (ITDP) and it is addressed to "policy makers, planners, city officials, developers, architects, urban designers, landscape designers, civil engineers, civil society organizations, and the interested public" [ITDP, 2017]. In order to achieve its objectives, the TOD Standard presents eight main principles together with measurable indicators that allow to assess current and future developments regarding their affinity with transit and walkable environments. After the overall analysis, a final score is obtained for each of the metrics considered in the TOD. This score leads to a label that qualifies an urban area.

Although the Transit Oriented Development objectives have scarcely been called into question, the possibility to apply the TOD Standard principles to different locations around the world has often been challenged. Several studies [Sung \& Oh, 2011; Cerin et al., 2007; Leslie et al., 2007] have sought to prove its robustness in environments physically and socially different from the American urban centers that originated the concept. In order to do so, complementary analyzing methods have been used, such as surveys [Kelly et al., 2011; Cerin et al., 2007; Sun et al. 2016], multiple regression models [Sung \& Oh, 2011] or in site measurements [Sun et al., 2016].

\subsection{Objective}

This work attempts to address the issue of abstraction when assessing complex urban realities. Although abstraction is essential in order to deal with data management and analytics, it is important to be aware of its limitations. Decisions are taken at each level of abstraction and these choices highly determine the final results obtained. Consequently, when assessing urban realities, being aware of the dangers of falling in over-simplifications and the consequences of making decisions based on partial models, should be acknowledged throughout the process. In addition, attempts of grasping their whole complexity should be made through different approaches and perspectives of information. This article argues that graphical representation through mapping can be an effective tool to add a different layer to purely numerical average-based analysis. It is especially important to address this issue in a moment when the availability of data and computational power are pressing urban decisions into relying on averages and scores of different parameters.

A clear example of this can be appreciated in the TOD Standard, a tool to assess walkability and Transit Oriented Development based on scores and averages that might not fully convey the reality of the place. This tool aims at being able to assess urban realities worldwide and, therefore, it is interesting to use it as a case study. This article aims to review the TOD Standard principles through graphical expression means, translating data into information-based drawings and comparing the results with the TOD quantitative scores. In this way, the study intends to show the potential of data-based mapping to communicate information and complement quantitative statistical analysis. The objective is to reconsider the perceived consistency of mapping as a central analysis tool and put its validity at the same level than other methods, engaging in its inherent subjectivity of interpretation. The transportation field has traditionally been strongly connected with quantitative methods, such as Large Scale Urban Models]. However, multiple voices claim that these approaches have not been successful in modeling urban real circumstances [[Klosterman, 1994]. 
In order to perform this study, an area around a major transit node in Paris, Saint-Lazare Station, has been analyzed both purely numerically and graphically following the principles of the TOD Standard. Paris choice was motivated by the objective of studying a walkable city with a complete transit network. Saint-Lazare station area provided a region around a major multimodal transit station with a generally positive walking environment located in a central area of Paris. The comparison of these two analysis has provided the opportunity to outline the benefits of complementing a study with graphical display instead of relying only on summarizing numerical scores.

\section{METHODOLOGY}

\subsection{Tools and Data}

The cartographic analysis has been carried out by means of the Geographic Information System (GIS) software ArcMap, which allows to display and explore GIS datasets for a study area, to assign symbols and create thematic map layouts [Esri, 2017]. The main GIS Spatial Analysis tools that were used in this study are known as "Create Buffers", "Summarize Within", and "Connect Origin to Destination (Travel mode: Walking Time)". These tools are of simple use and available in most GIS software, not demanding neither high GIS analysis skills or computation power. This approach responds to the aim of ensuring a similar analysis could be accessible for a wide range of collectives in the city. In line with this objective, the Data used in this study was all available in Open Data sources.

\subsection{Study of Saint-Lazare area, Paris.}

Paris is a reference city in terms of compactness, diversity, public space quality and extension and coverage of its subway [Parcerisa \& Rubert de Ventós, 2001]. This transit system is complemented by a bus network, metropolitan rail, a bicycle and electrical car renting system and 6 terminus train stations. Saint-Lazare is one of this 6 multimodal train station located in the North-center of Paris.

A TOD based study of 32 different transit stations in five cities around the world, carried out through course exercises of urbanism studies from the Architecture School in Granada (Spain), showed that Paris was the city with a higher average TOD score among the studied ones (London, Paris, Los Angeles, Santiago de Chile, Istanbul). The "Observatoire de la Mobilité en Île-deFrance" (OMNIL) supports this view with several data about users' mobility habits. With 4.15 trips per day, Parisians are the most mobile of the Île-de France region. In Paris, the part of the population subscribing to public transportation is $51 \%$, compared with a $36 \%$ in the Île-de-France region. Parisians also own lower automobile equipment; more than half of Parisians households do not own a car, which is almost twice more than in the surrounding departments. Regarding the travel motivations, "Required trips", defined by the OMNIL as associated with work or studies, represent only $38 \%$ of the total number. Among all the other travels not linked with work or studies, the prevailing category gathers leisure and activities motivated trips (18\%), closely followed by the purchases motivated ones $(16 \%)$. In terms of transport modes, walking is by far the most used by the Parisians. The percentage of walking over the other modes ranges between $46 \%$ (home-leisure commutes) and 79\% (home-purchases commutes). The only exception is the home-work commute for which they favor public transportation [OMNIL, 2013].

The Paris-Saint-Lazare Station, is one of the six great terminus railway stations in Paris. Located in the Europe neighborhood in the $8^{\text {th }}$ arrondissement, it is the major head-end of the rail network 
inherited from the "Companie des chemins de fer de l'Ouest" (1855-1909), serving most of the Normandie region and the west suburbs of Paris. The first current buildings of the station were built in 1840-1841, being expanded several times between 1852 and 1892, as rail traffic was developing and with the great expansion of 1889 for the Universal Exhibition in Paris [SNCF, 2015].

The development of rail traffic, together with the incorporation of city and regional transit systems and other uses, transformed Saint-Lazare from a classical terminus rail station into a Multimodal pole. A major restructuration project took place between 2003 and 2012, giving shape to this contemporary interpretation of a transportation node. A vast $10000 \mathrm{~m}^{2}$ commercial hall (Figures 1 and 2) is now accessible from the lobby and connects the three levels of the subway, street and train platforms (Figure 3), receiving the commuting of the 27 train platform lines, the city and its other transit systems [SNCF, 2015]. There is a strong synergy between the train station and the commercial gallery as $68 \%$ of the visitors use the commercial facilities every time they traverse the station [NERA, 2016]. Nowadays, with about 100 millions of passengers a year (105.3 in 2015), Saint-Lazare is the second busiest train station of Paris and France (105 324691 passengers 2015) and among the busiest transport stations in Europe. [ [dataset] SNCF Open Data, 2015].
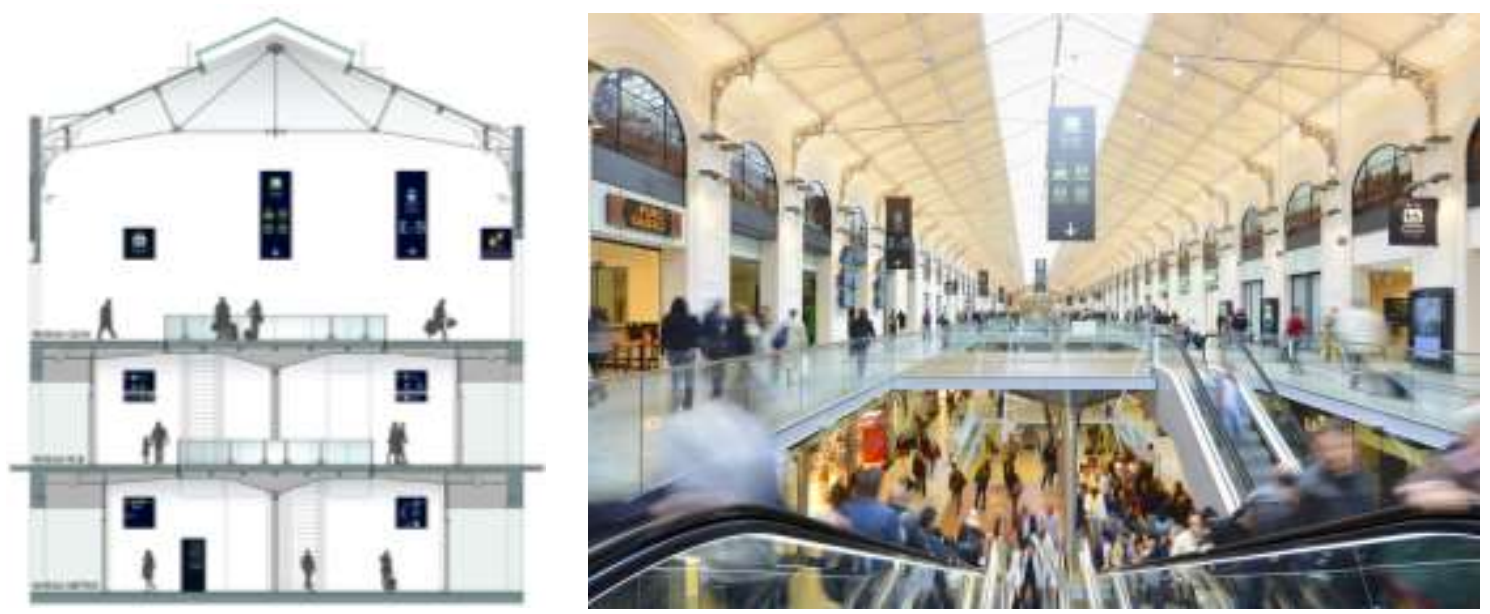

Figure 1 and 2: Saint-Lazare central distribution and shopping hall. Sources: AREP Designlab (Fig.1), gqmagazine (C) François Renault/Photononstop (Fig.2).

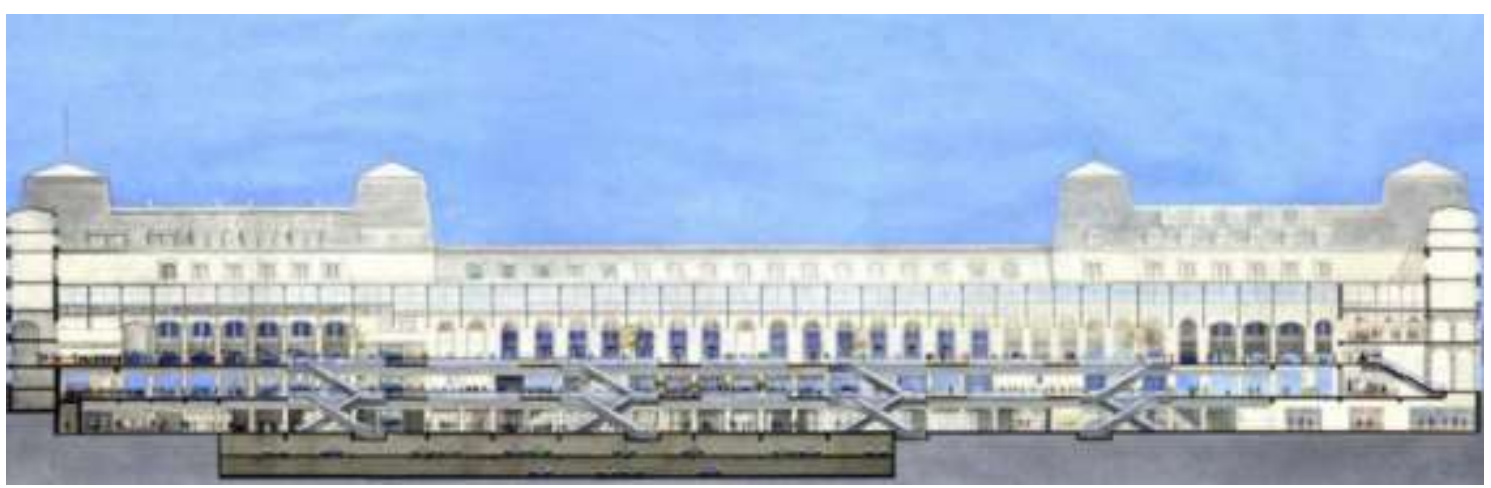

Figure 3: Longitudinal section of the station. Different levels interrelation. Source: AREP.

The studied area, of $4.45 \mathrm{~km}^{2}$ around the station, straddles two administrative districts or "arrondissements": the $8^{\text {th }}$ and the $9^{\text {th }}$, being surrounded by important axes at the scale of the city (Batignolles, Malesherbes and Haussman Boulevards; and Saint-Lazare street). The area's regular and dense urban fabric is disrupted by the presence of Saint-Lazare Station and its railways 
(Figure 5). These elements physically divide the space, but also allow to open a large visual perspective, a special feature in Paris' compact urban tissue (Figure 6).

The residential density of the $8^{\text {th }}$ and $9^{\text {th }}$ arrondissement are respectively $10064.68 \mathrm{inhbt} / \mathrm{km}^{2}$ and $27281.65 \mathrm{inhbt} / \mathrm{km}^{2}$ [INSEE, 2011]. This residential density is especially low in the $8^{\text {th }}$ - compared with Paris average density of $21067 \mathrm{inhbt} / \mathrm{km}^{2}$ [INSEE, 2014], probably due to a major area being part of the Central Business District of Paris, which offers the largest office park of Paris [APUR, 2007]. The average annual income in the $8^{\text {th }}$ and $9^{\text {th }}$ arrondissement, respectively $42531 €$ and 32 $532 €$, are much higher than the $25830 €$ average of Paris [INSEE, 2011]. The unemployment rate is also low compared with the $9.0 \%$ baseline of Paris: $8.3 \%$ in the $9^{\text {th }}$ district, and $6.0 \%$ in the $8^{\text {th }}$ which is the lowest rate among all the 20 arrondissement [INSEE, 2012]. Regarding the socioeconomic classes, the rate of higher intellectual occupations is higher in those two $8^{\text {th }}$ and $9^{\text {th }}$ districts than the average of Paris (31.6\% and 36.4\% against $28.1 \%$ ) and the rate of employees is lower (11.8\% and $11.4 \%$ against $13.1 \%)$ [INSEE, 2012].

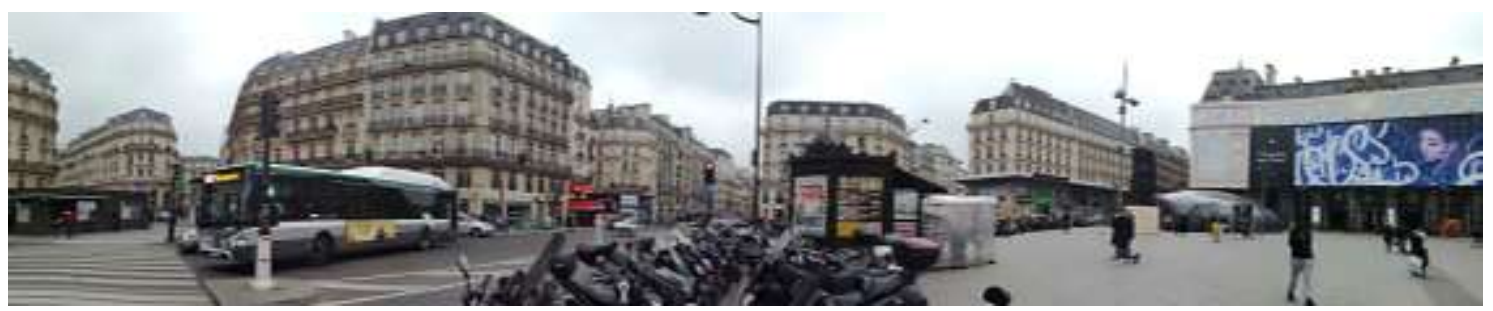

Figure 4: Saint-Lazare station (on the right) and its urban surroundings. Source: the autors.
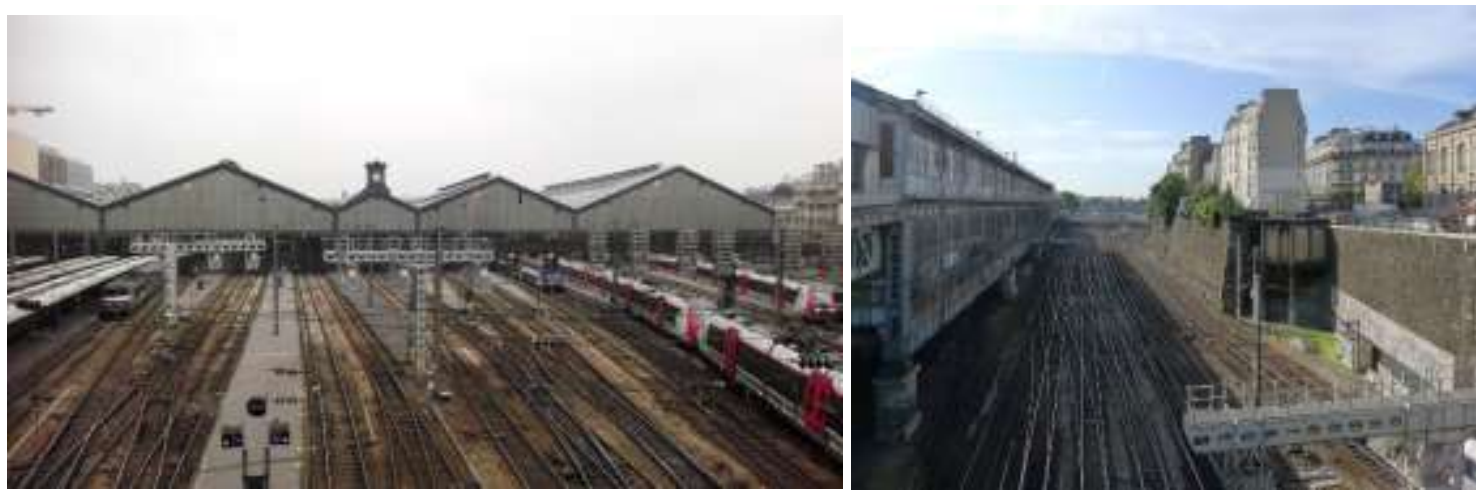

Figure 5 and 6: Depressed railways and the perspective they create. Sources: the autors (Fig.1), Mbzt @) (Fig.2).

In the two "arrondissements" intersected by the studied zone (8th and 9th), with 4.43 trips per day, residents are more mobile than the Paris average (4.15). The part of active travel modes (nonmotorized: walking, cycling, running, skateboarding, etc. [PHAC, 2014]) is 59.4\%. The use of car is very low, only $6.8 \%$, and about one third of the trips are made on public transportation $(32.7 \%)$. Among the 1611000 trips made within Île-de-France by the inhabitants of the 8 th $/ 9^{\text {th }}$ arrondissement, $26 \%$ are made within the area, $40 \%$ within Paris, and the rest toward other departments. Regarding the morning commutes, the 8th-9th zone is a receiver area, with a ratio between the numbers of received and emitted trips of more than 1.5 , probably a consequence of the high number of jobs present in the area [OMNIL, 2013].

The chosen scope of the station area of study is a linear crow-fly 500m radius buffer around each station's entrance, which corresponds to a walking time of 10 minutes at an average speed of $3 \mathrm{~km} / \mathrm{h}$ (Figure 8 ). The $3 \mathrm{~km} / \mathrm{h}$ speed is the one recommended in the TOD Standard, including the intersections waiting time. This speed is also consistent with the pedestrian speed considered in Paris by the City's planning services, $1 \mathrm{~m} / \mathrm{s}$ or $3,6 \mathrm{~km} / \mathrm{h}$ without waiting times [Le Parisien, 2010]. For the walking time or distance, the TOD Standard recommends to use a "reasonable walkable 
distance" of the transit station, according to local standards. In this study, a walking time of 10 minutes was chosen, a time period based on the proximity trips proposed in Marquet and MirallesGuasch study [Marquet \& Miralles-Guasch, 2015]. This 10 minutes walking time together with a 3 $\mathrm{km} / \mathrm{h}$ speed, corresponds to the $500 \mathrm{~m}$ radius scope of this study, similar to other works developed about compact cities [Sung \& Oh, 2011]. A network analysis based service area was regarded as not appropriate, considering the TOD approximate approach to the definitions of these extents and the general aim of this work.
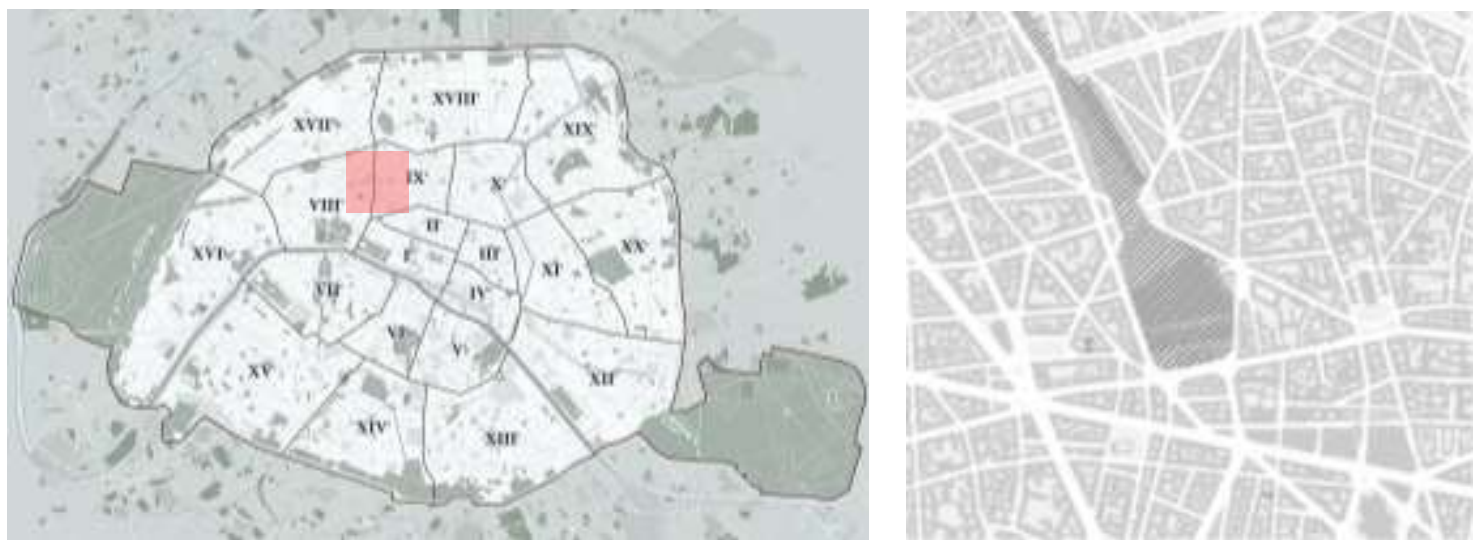

Figure 7 and 8: Location in the city and perimeter of the studied zone. Source: planparis360.fr and the authors.

The main data source was the site "Open Data Paris" [Open Data Paris], where the services of the City of Paris and their partners publish geolocated datasets. The Open Data website of the "APUR" (Atelier Parisien d'URbanisme) [Open Data APUR], an urbanism agency gathering local collectivities of the Ile-de-France region and working as a non-profit organization, was also extensively used.

One specific dataset, concerning the location of transport stations and stops, was downloaded from "Open Data RATP", the open data website of the autonomous operator of Parisian transports "RATP" (Régie Autonome de Transports Parisiens) [Open Data RATP]. The precise road plan of the studied zone was obtained in DWG format from the Direction de la Voirie et des Déplacements - Division des plans de voirie de la Ville de Paris, a municipality open service. The location of public projects was obtained from the Local Urbanism Plan (PLU) of Paris.

Finally, when the data was not existent in any of the previously mentioned sources, layers were created on ArcMap based on direct observations through Google Street View or in the field.

\subsection{Measurement methods}

The measurements have been carried out following the TOD Standard version 2.1 [ITDP, 2014], which defines 8 "Principles" divided in "Metrics". However, the existence of the TOD Standard 3 [ITDP, 2017] should be acknowledged, as this version modifies certain metrics and measurement methods of the Standard.

\begin{tabular}{|l|l|}
\hline Principles & Metrics \\
\hline \multirow{4}{*}{1. WALK } & 1.1. Walkways \\
\cline { 2 - 2 } & 1.2. Crosswalks \\
\cline { 2 - 2 } & 1.3.Visually Active Frontage \\
\cline { 2 - 2 } & 1.4. Physically Permeable Frontage \\
\cline { 2 - 2 } & 1.5. Shade \& Shelter \\
\hline 2. CYCLE & 2.1. Cycle Network \\
\hline
\end{tabular}




\begin{tabular}{|l|l|}
\hline \multirow{4}{*}{ 3. CONNECT } & 2.2. Cycle Parking at Transit Stations \\
\cline { 2 - 2 } & 2.3. Cycle Parking at Buildings \\
\cline { 2 - 2 } 2.4. Cycle Access in Buildings \\
\hline 4. TRANSIT & 3.1. Small Blocks \\
\hline \multirow{4}{*}{ 5. MIX } & 4.1. Prioritized Connectivity \\
\hline 6. DENSIFY & 5.1. Complementary Uses \\
\hline \multirow{2}{*}{ 7. COMPACT } & 5.2. Accessibility to Food \\
\cline { 2 - 2 } & 5.3. Affordable Housing \\
\hline \multirow{4}{*}{ 8. SHIFT } & 6.1. Land Use Density \\
\cline { 2 - 2 } & 7.1. Urban Site \\
\hline & 8.2. Transit Options \\
\cline { 2 - 2 } & 8.1. Off-Street Parking \\
\hline & 8.3. Roadway area \\
\hline
\end{tabular}

Table 1: Structure of the TOD Standard - The 8 Principles and their metrics.

All the results and scores were obtained following the TOD Standard indications. 13 metrics need further explanations, either because the criteria were slightly modified to better adjust to the case study or because their complexity demands a more detailed explanation $(1.1,1.2,1.5,1.3,2.2$, $2.3,3.2,5.1,5.3,6.1,7.1,8.1,8.3)$.

For the walkways metric (1.1), three widths were mapped: smaller than $1.40 \mathrm{~m}, 1.40-1.80 \mathrm{~m}$ and larger than 1.80. In Paris, the minimum width for a sidewalk to be wheelchair-accessible is $1.40 \mathrm{~m}$, free of all obstacles. However, it is recommended to let a $1.80 \mathrm{~m}$ width for a comfortable walking and allow two wheelchairs to cross each other [Mairie de Paris, 2012].

In the crosswalks metric (1.2), an intersection was considered "complete/crossable" when there were qualifying safe crosswalks in each street forming the intersection, on each of the two sides of the intersection (Figure 9a) as indicated in the TOD Standard. In addition, for this case, if one of the streets of the intersection was pedestrian or with only one car lane, and did not have a crosswalk on each side of the intersection, the intersection was also recorded as "complete/crossable". Considering these cases as crossable responded to observations of the urban tissue and pedestrian behavior in the area (Figure 9b).

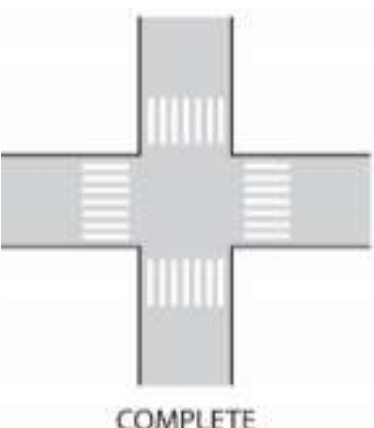

COMPLETE

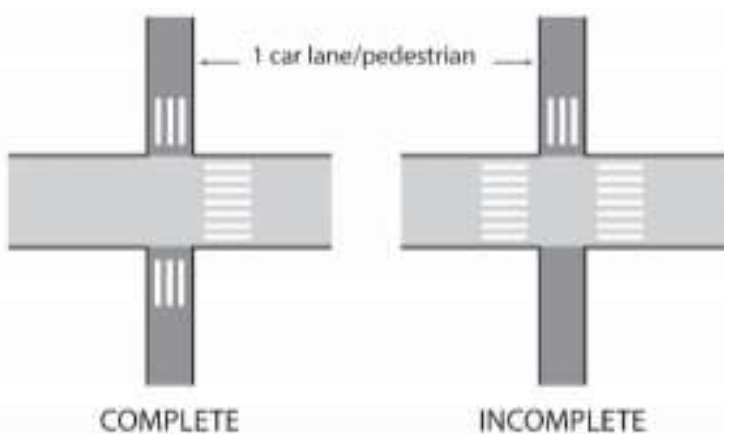

COMPLETE

INCOMPLETE

Figure 9a: Intersections considered as "complete" or "incomplete". 


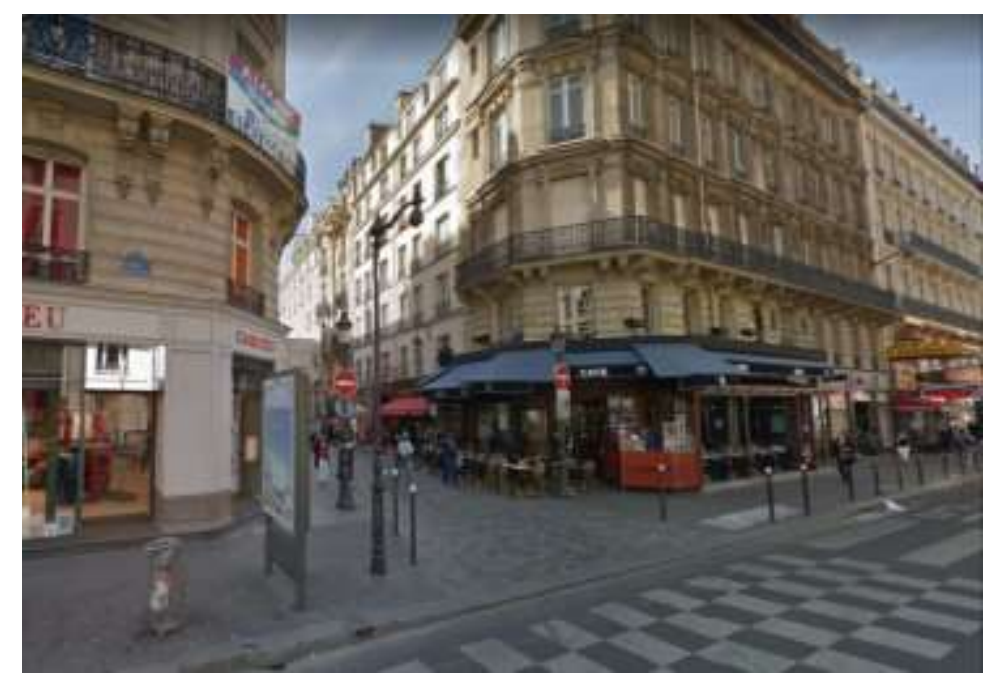

Figure 9b: Image of a type 2 “complete intersection”. Source: google street view

In the case of the visually active frontage metric (1.3), when assessing isolated buildings in a plot, the construction - free space proportion was analyzed in order to classify the ensemble into "open space" or "building" type. In addition, the frontages of landscaped fenced-off spaces with visually permeable features were considered active, while the frontages overlooking railway spaces were considered inactive, due to not being an accessible open space. Opposite to the TOD Standard, visually open private patios and porches were considered as active, as their perceivable activity level was understood as equal as or higher than interior spaces visually connected through windows. Moreover, a complement to the visually active frontage (1.3) was added to the study in order to assess perceived activeness more thoughtfully. This new metric, the usable active frontage (1.3b), collects all visually permeable frontages that are also accessible by the pedestrian, such as commercial units or public buildings and offices. In this case, the TOD segmentation criteria was not applied bringing as a result a more detailed mapping where each plot was assessed individually and not as a percentage of a segment between two intersections. For the shade and shelter metric (1.5), bus stops and trees were the elements included in the study, as in the area there were no other fixed shade and shelter giving elements. The shade area around trees was approximated as a $6.6 \mathrm{~m}$ radius buffer around the location point, the average radius of the most common trees in the area [Chanes, 2009].

Regarding the cycle park at transit stations metric (2.2), the bike racks considered were those installed by the municipality and the shared Public Bike System stations (Vélib' [Mairie de Paris/SOMUPI, 2010]). The information about the weather protected storage was not available at the open databases. All transit stations of the area were considered as "applicable transit stations", as they have direct connection with Saint-Lazare, a "high-capacity" station. The shared Public Cars System stations (Autolib' [Autolib', 2017]) were also included, as the TOD parameters consider shared vehicle stations as transit stations. In order to measure the surface distance from a transit station, all the different accesses of the station were analyzed. Therefore, each transport station's entrance or exit was subjected to the criterion of cycle parking presence within a $100 \mathrm{~m}$ distance, increasing in this way the level of requirements. In the case of cycle parking at buildings metric (2.3), as in cycle park at transit stations (2.2) the only available data are those provided by the municipality. Other privately installed parking facilities might complement and enlarge the data considered.

In the case of prioritized connectivity metric (3.2), covered streets and main tracks of public parks were considered as pedestrian paths that can generate intersections. 
The Mix principle had several metrics that should be addressed in order to provide assessable results. In the case of the complementary use metric (5.1), three different types of use were identified within the area: housing (individual or collective), industrial or tertiary, and mixed-use (i.e a mix of the two previous categories in the same building). Regarding the accessibility to food metric (5.2), the following categories were selected as sources of fresh food according to the TOD Standard's definition: fruits and vegetables stores, general alimentation stores, supermarkets and mini-markets, butcheries, organic food stores and catering stores, which in France tend to sell fresh food as well as processed one. In compact cities such as Paris, the $500 \mathrm{~m}$ baseline can be lowered. In this line, buffers of a $200 \mathrm{~m}$ and $100 \mathrm{~m}$ radius were drawn around sources of fresh food, in order to visualize the proportion of buildings that are within these radial buffer areas. Nevertheless, it is to be noted that these displayed distances, even though more perceptible, are not walking distances. In the case of affordable housing (5.3), due to open data availability, only financed social housing was considered in the study, which includes the following categories: family dwellings, student residences, establishment of accommodation for dependent old people (EHPAD), transition centers, emergency shelters and hostels for young workers, migrant workers or disabled people. Only the number of social housing residential units within the selected IRIS (Îlots Regroupés pour l'Information Statistiques) was taken into account, giving thus a low overall number.

In the case of the use intensify metric (6.1), the residential inhabitants density was allocated according to IRIS area units (Îlots Regroupés pour l'Information Statistiques) by the "INSEE" (National Institute of Statistics and Economic Studies). When their limits did not correspond to the delimited scope's ones, the total number of inhabitants calculation only included the IRIS that had their centroid in the studied area. On the other hand, geolocated information about the numbers of jobs and visitors in Paris was not available in open data. To complement this information, the land use density was incorporated in the blocks where the Floor Area Ratio and the Gross Area Ratio were available.

The urban site metric (7.1) quantifies the developable site or property area. In the case of Saint Lazare area, being part of the highly consolidated tissue in Paris center, there are not any unconstructed plots with constructing possibilities. Developing possibilities are based in restoration, adaptive reuse and rehabilitation strategies. Consequently, this principle was disregarded as not quantifiable in our location. To give an insight of the renewal pace of the area, plots with current public projects were included in the data.

Regarding the off-street parking metric (8.1), an estimation based on professionals experience was made with the number of parking plots, the only available open data, and the average surface of a plot considered as $35 \mathrm{~m}^{2}$. In the case of the roadway area metric (8.3), the traffic area was estimated through the length of each lane, the number of lanes in each street section and the usual width of traffic lanes in Paris, being 3m [APUR, 2002]. The bus and taxi lanes, were recorded as traffic lanes as, even though it is prohibited, observations showed that a large amount of regular cars tended to use them and, therefore, they were perceived as traffic lanes from the pedestrian point of view.

\section{RESULTS AND DISCUSSION}

This section will present both the quantitative results and the graphical results obtained and, subsequently, their comparative.

\subsection{Quantitative Results}

The Metrics, embedded in their principles, are those of the TOD Standard 2.0. The Results are the summary of the measurements, presented through percentages, distances and integers, following 
the TOD Standard 2.0 indications. The TOD Standard's baselines are the references used to translate these Results into Scores. Therefore, the final Score is a calculation based on the indications of the TOD Standard 2.0

\begin{tabular}{|c|c|c|c|c|}
\hline & Metric & $\begin{array}{l}\text { Saint-Lazare Station } \\
\text { area results }\end{array}$ & TOD Standard's baseline & Score \\
\hline \multirow{6}{*}{. } & 1.1.Walkways & $97.9 \%$ & Less than $100 \%$ & $0 / 3$ \\
\hline & 1.2.Crosswalks & $71 \%$ & Less than $100 \%$ & $0 / 3$ \\
\hline & 1.3.Visually Active Frontage & $92.2 \%$ & $90 \%$ or more & $6 / 6$ \\
\hline & 1.3.b.Use Permeable Frontage & $59.5 \%$ & & \\
\hline & $\begin{array}{l}\text { 1.4.Physically Permeable } \\
\text { Frontage }\end{array}$ & 3.08 & Between 3 and 5 & $1 / 2$ \\
\hline & 1.5.Shade \& Shelter & $17.40 \%$ & Less than $75 \%$ & $0 / 1$ \\
\hline \multirow{4}{*}{ în } & 2.1.Cycle Network & {$[800 \mathrm{~m} ; 1000 \mathrm{~m}]$} & More than $200 \mathrm{~m}$ & $0 / 2$ \\
\hline & $\begin{array}{l}\text { 2.2.Cycle Parking at Transit } \\
\text { Stations }\end{array}$ & 264 out of 338 & Not all & $0 / 1$ \\
\hline & 2.3.Cycle Parking at Buildings & & & \\
\hline & 2.4.Cycle Access in Buildings & Interior access allowed & Not required & $0 / 1$ \\
\hline \multirow{3}{*}{ 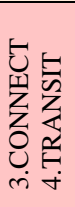 } & 3.1.Small Blocks & $25.4 \%$ over $190 \mathrm{~m}$ & More than $10 \%$ & $0 / 10$ \\
\hline & 3.2.Prioritized Connectivity & $0.98 \%$ & Above 0.5 , below 1 & $1 / 5$ \\
\hline & 4.1.Walk Distance to transit & Maximum 400m & Less than $500 \mathrm{~m}$ & OK \\
\hline \multirow{3}{*}{$\sum_{\substack{x \\
i}}^{x}$} & 5.1.Complementary Uses & $51.9 \%$ & Between $50 \%$ and $70 \%$ & $5 / 10$ \\
\hline & 5.2.Accessibility to Food & $100 \%$ & $80 \%$ or more & $1 / 1$ \\
\hline & 5.3.Affordable Housing & $4.1 \%$ & Less than $15 \%$ & $0 / 4$ \\
\hline \multirow{3}{*}{ 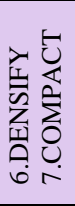 } & 6.1.Land Use Density & $\begin{array}{l}73871.65 \text { users } / \mathrm{km}^{2} \\
\text { Opéra baseline: } \\
62673.43 \text { users } / \mathrm{km}^{2}\end{array}$ & Higher than the baseline & $15 / 15$ \\
\hline & 7.1.Urban Site & & & \\
\hline & 7.2.Transit Options & 30 points & Maximum of 5 points & $5 / 5$ \\
\hline \multirow{3}{*}{ 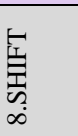 } & 8.1.Off-Street Parking & $5.3 \%$ & $10 \%$ or less & $10 / 10$ \\
\hline & 8.2.Driveway Density & 1.7 & 2 or less & $2 / 2$ \\
\hline & 8.3.Roadway area & $6.7 \%$ & $15 \%$ or less & $8 / 8$ \\
\hline
\end{tabular}

Table 2: Quantitative results from the TOD Standard scoring system.

The walk principle (1) overall achieves positive results according to the TOD Standard, except for the shade and shelter metric (1.5). In the case of the walkways metric (1.1), the percentage of safe and wheelchair-accessible walkways, wider than $1.40 \mathrm{~m}$ according to Paris regulations, is $97.9 \%$. This score is the second top one, between $95 \%$ and $99 \%$ in the TOD Standard. However, Paris regulations consider $1.80 \mathrm{~m}$ to be the minimum recommended width for a comfortable walking and allow two wheelchairs to cross each other. In this case, the rate is $85.7 \%$, less than the TOD Standard' $90 \%$ minimal score for wheelchair accessible walkways. For the crosswalks metric (1.2), the percentage of intersections with safe, wheelchair-accessible crosswalks in all directions is $70.9 \%$. Therefore, the metric does not obtain any points, as the TOD Standard only baseline is $100 \%$. Regarding the visually active frontage metric (1.3), a $92.2 \%$ frontages are active ones, which is more than $90 \%$ and thus at the top TOD Standard score. In the case of the usable active frontage (1.3b), a more restrictive criterion, the rate of "use-permeable" frontages is reduced to $59.5 \%$.

For the physically permeable frontage metric (1.5), the average number of entrances per $100 \mathrm{~m}$ of block frontage is 3.1, an intermediate score between 3 and 5 that obtains 1 out of 2 points.

For the shade and shelter metric (1.5) only $17.4 \%$ of the street segments are considered shaded or sheltered, which is way less than the $75 \%$ reference of the TOD Standard. 


\section{Cycle principle (2)}

In the case of cycle network (2.1) only $15.4 \%$ of the street segments have "safe cycling conditions", which is way below the $90 \%$ reference for areas in development. Moreover, the maximum walk distance to a safe cycling street is between 800 and $1000 \mathrm{~m}$, which is way above the $200 \mathrm{~m}$ maximum reference for station areas. For the cycle parking at transit stations metric (2.2), 74 station entrances (out of 338) do not fulfill the TOD Standard criterion, as cycle racks are not provided within $100 \mathrm{~m}$ of the station entrance. Regarding cycle parking at buildings (2.3), there were no available data concerning the private cycle parking (inside buildings), only parkings in the public space and "Vélib" stations were considered. For information, according to the city council recommendations, all the buildings above $250 \mathrm{~m}^{2}$ should have cycle parking. This would represent $94,7 \%$ of the buildings, way more than the $25 \%$ baseline of the TOD Standard. For the metric cycle access in buildings (2.4), the city of Paris has not a specific regulation on the subject. However, in general, buildings allow the entrance of bicycles when there is a dedicated storage inside. When this is not the case, it depends on the condominium regulation, although it is generally allowed as long as bicycles are not stored in the common spaces [Mairie de Paris, 2017].

\section{Connect principle (3)}

For the small blocks metric (3.1), a total of $25.4 \%$ of the blocks within the station area are over the $190 \mathrm{~m}$ in length. This measurement corresponds with the TOD Standard 2.0 category of "More than $10 \%$ of blocks within the station area are over $190 \mathrm{~m}$ in length" and, therefore, assigns the minimal TOD Standard score to the area (0). In the case of prioritized connectivity metric (3.2), the prioritized connectivity ratio of pedestrian intersections to motor vehicle intersections is 0.98 , which falls into the second intermediate category "between 0.5 and 1 " corresponding to one point in the scoring system.

\section{Transit (4)}

For the walk distance to transit (4.1), the maximum walking distance from a building entrance to a direct transit station is of approximately $400 \mathrm{~m}$, less than the 500m TOD Standard baseline.

\section{$\operatorname{Mix}(5)$}

In the case of complementary use metric (5.1), the predominant use in the station is "tertiary or industrial", that is to say no-residential. This use takes $51.9 \%$ of the total floor area, which is slightly more than the 50\% and less than $70 \%$ the TOD Standard 2.0 reference. Consequently, following its directions, a scores of $5 / 10$ is assigned. The second more frequent use is "mixed". Overall, the area is contextually complementary. For the accessibility to food metric (5.2), 100\% of the building entrances are within a $500 \mathrm{~m}$ radius, considered as "within walking distance" by the TOD Standard, of a source of fresh food. In addition, $100 \%$ of the residential buildings are within a 200m radial distance to a source of fresh food - all buildings in the area except the "Opéra Garnier" - and $78.2 \%$ of the buildings are within a $100 \mathrm{~m}$ walking distance to a source of fresh food. Therefore, considering the $500 \mathrm{~m}$ baseline distance of the TOD Standard, it can be stated that the area is well provided with sources of fresh food. Regarding the affordable housing metric (5.3), $4.1 \%$ of all residential units in the area are considered affordable, less than the $15 \%$ minimal TOD Standard baseline for station areas. However, the criteria used in this study for affordable housing was very strict and, therefore, the results might be underestimated.

\section{Densify (6)}

For the use intensity metric (6.1), the total resident population of the area is 40733 inhabitants. The average concentration of jobs in the $8^{\text {th }}$ arrondissement is $50515 \mathrm{jobs} / \mathrm{km}^{2}$ and, in the $9^{\text {th }}, 57$ $264 \mathrm{jobs} / \mathrm{km}^{2}$. For the same job concentrations considered in the selected IRIS, the total number of jobs would correspond to 112700 . Therefore, the approximated "Use intensity" - without considering the visitors factor - for the selected IRIS of the zone is 155827 , or $73871.6 \mathrm{users} / \mathrm{km}^{2}$. As a comparison, a neighboring area around the metro station Opéra, with a similar use and also being part of the "business district" has a Use Intensity of $62673.4 \mathrm{users} / \mathrm{km}^{2}$. At a slightly larger 
scale, the $10^{\text {th }}$ arrondissement, which includes the Gare du Nord and Gare de l'Est stations has a "Use intensity" of $59270.6 / \mathrm{km}^{2}$ (94 474 inhabitants and 76818 jobs). Finally, the municipality of Paris had 2210849 inhabitants and 1937600 jobs in 2015, which represents a Use intensity of $39359.1 / \mathrm{km}^{2}$. Consequently, the Use Intensity of the studied zone is more than $5 \%$ higher than the various baseline intensities previously mentioned, which ensures the maximum points number in the TOD Standard's scoring system.

\section{Compact (7)}

In the case of the transit options metric (7.2), 26 regular transit lines - 6 metro lines (lines 3, 7, 9, 12, 13 and 14), 18 bus lines (lines 20, 21, 22, 24, 26, 27, 28, 29, 32, 42, 43, 53, 66, 68, 80, 81, 94, 95) and 2 regional lines (RER A and E) - are present in the area, as well as a bike share system ("Vélib") with 38 stations and a car sharing system ("Autolib") with 19 stations. This ensemble exceeds the maximal TOD Standard score for the area.

\section{Shift (8)}

As for the off-street parking metric (8.1), the total area of off-street parking is $235095 \mathrm{~m}^{2}$, which represent $5.3 \%$ of the total area. This percentage is below $10 \%$ and thus gets the maximal score, as off-street parking is considered as "non-essential" and, in walkability terms, has a negative connotation. For the driveway density (8.2), the average number of driveways per $100 \mathrm{~m}$ of block frontage is 1.7, a score below the limit of 2 that allows to get the points of this metric. Regarding the roadway area metric (8.3), the total approximated motor vehicle area represents $6.7 \%$ of the site area, which is less than the $15 \%$ threshold in the TOD Standard and thus achieves the maximum score. 


\subsection{Graphic Results}

The following figure summarizes the graphic results. Some principles, less complex than the others, have been joined in a single graphical representation for the sake of clarity and information condensation.

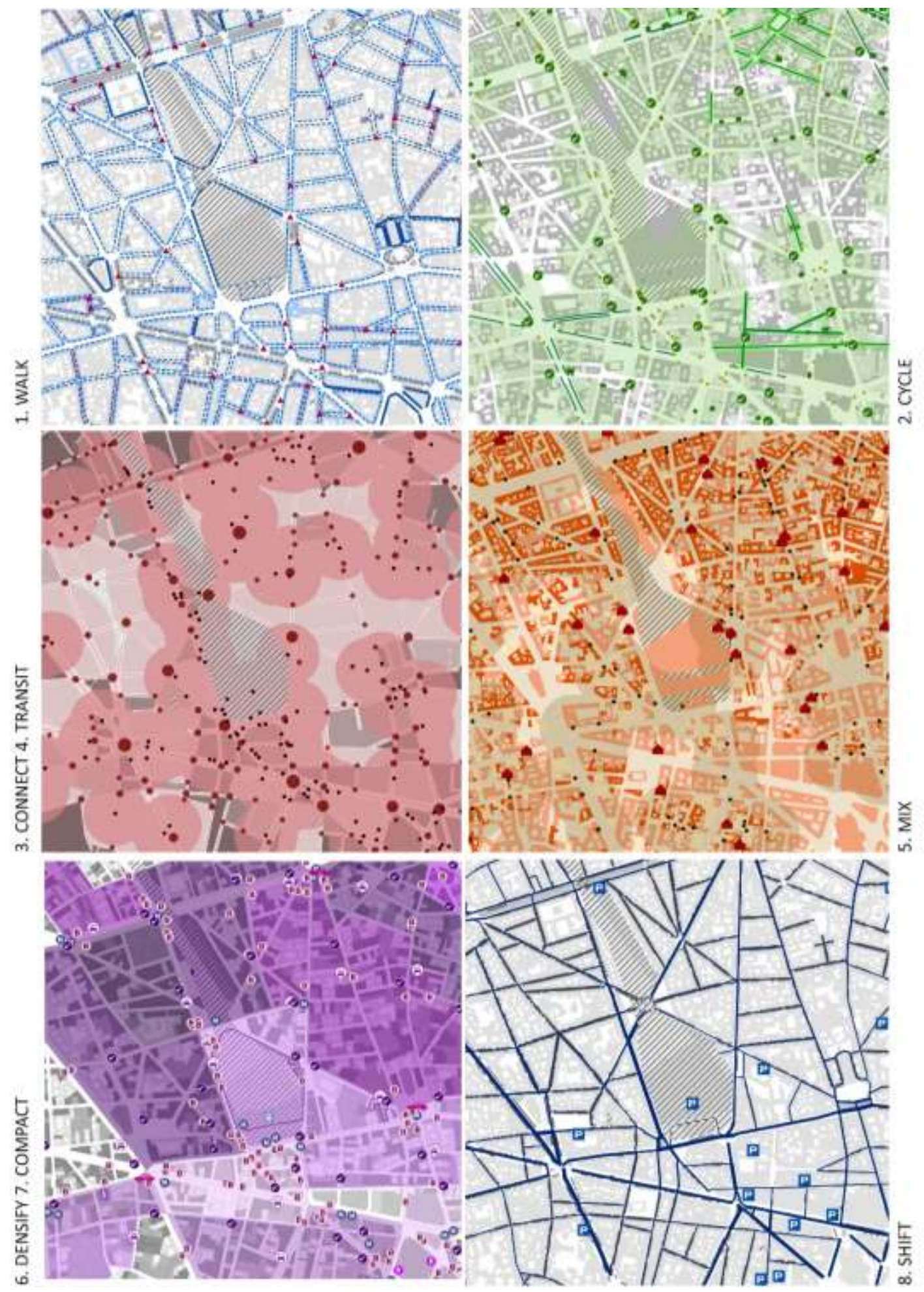

Figure 10: Maps displaying the 8 principles of the TOD Standard and their metrics generated with ArcGIS. Source: the authors 


\subsection{Discussion}

In order to illustrate the importance of considering graphical expression a key part of our analysis toolset, three main principles have been selected to discuss from this point of view: walk (1), cycle (2) and mix (3). Within these principles, several metrics have been highlighted in the discussion: visually active frontage (1.3), the use active frontage (1.3b), the shade and shelter (1.5), the cycle network (2.1), the cycle parking at transit stations (2.2) the cycle parking at buildings (2.3), the complementary uses (5.1), the accessibility to food (5.2) and the affordable housing (5.1).

\subsubsection{Walk}

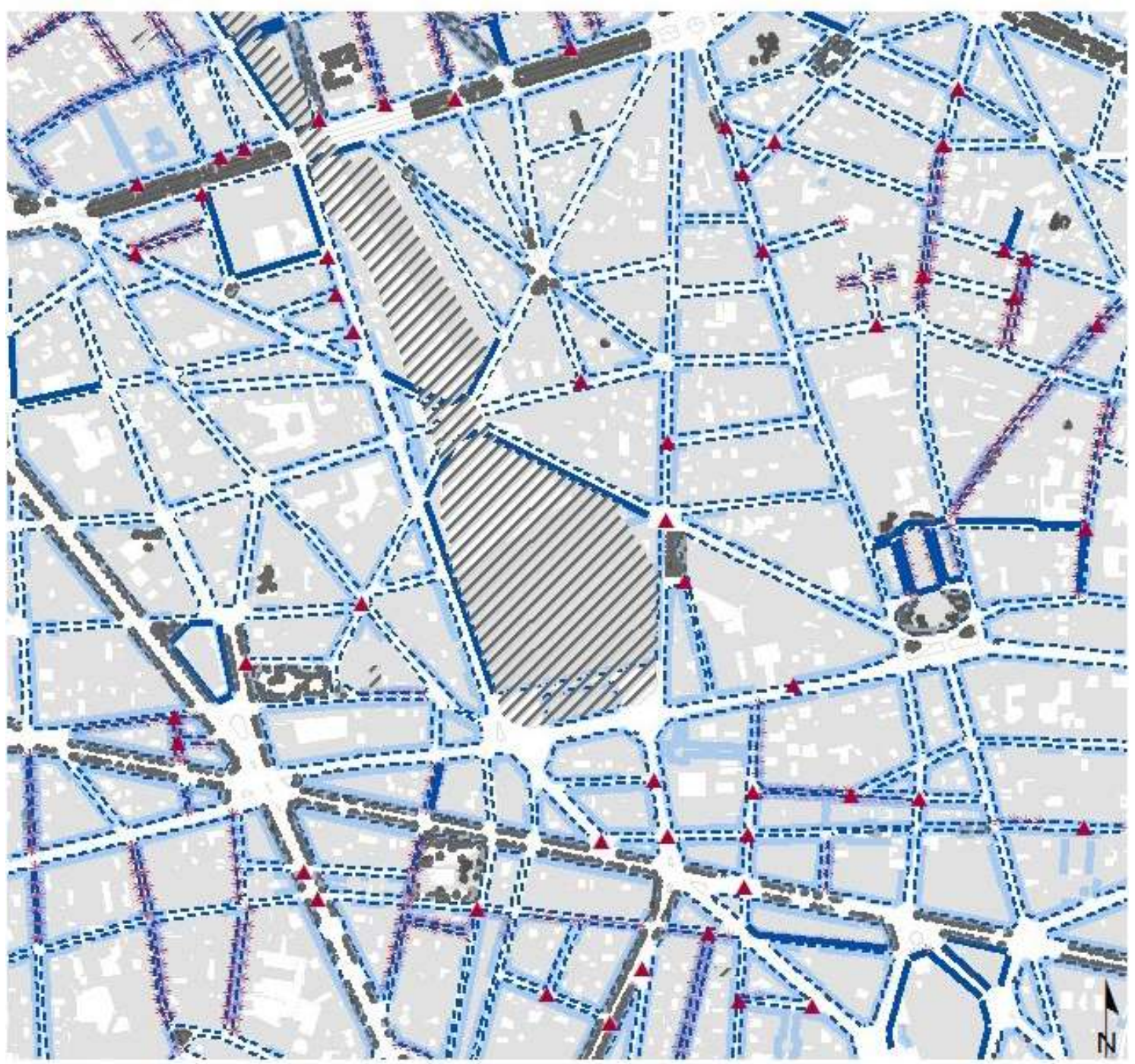

\section{Shade and shelter Visually active frontage Walkways}

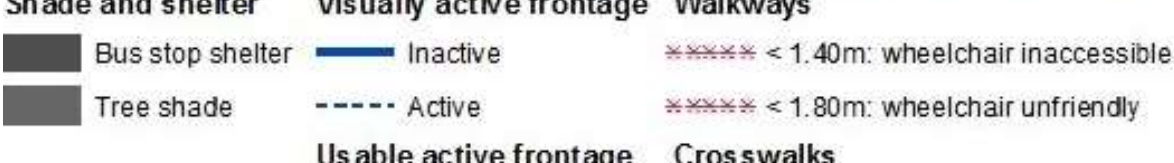

\section{Us able active frontage Crosswalks}

A Intersections with incomplete crosswalks

Figure 11: Four of the metrics of the walk (1) principle, the walkways (1.1), the visually active frontage (1.3), the use active frontage (1.3b) and the shade and shelter (1.5). 
Regarding the visually active frontage metric (1.3), the non- active façades can all be traced to specific locations. A more accurate observation of the area, allows to identify their connection with singular buildings, such as "Saint Lazare" train station, the "Opéra Garnier", "l'Église de la Trinité", "l'Église Saint-Agustin" and the "Lycée Chaptal". Several conclusion can be drawn from these observations. Firstly, a certain kind of public buildings might be very opaque due to historical reasons such as visual or physical protection or available construction techniques. Secondly, since most of the opaque buildings are part of the public property, this might seem easier to address by public administrations. However, as historical monuments tend to be the ones offering opaque façades, if heritage is to be preserved, it may be difficult to change this situation. In any case, this diagnosis allows to evaluate these situations and invest in reinforcing active frontages in opposite and surrounding façades.

In the case of the Use active frontage (1.3b), the spatial distribution allows to identify a group of blocs without any "use-permeable" facades, corresponding to a residential area, which was not possible with the visually active frontage metric, in which this area appears as active as the remaining of the studied perimeter. The graphical representation of the metric shows that façades that are no use-permeable are not evenly distributed around the area, but clustered in a specific residential location.

For the Shade and Shelter metric (1.5), a similar conclusion can be drawn. Trees are not homogeneously distributed in the area, being concentrated along major avenues, around squares places and public parks. Consequently, although the TOD Standard quantitative score might be very low, in fact, tree's shades are located in the most necessary spaces; open and public areas that are less protected from sun and other climate conditions. The graphical expression of this metric does not only contribute in detecting an uneven distribution but also assessing its relation with other elements of the urban environment. In addition, this observation might lead us to other conclusions, such as the importance of considering other sheltering elements like buildings and the street urban canyon [Garcia-Nevado et al., 2016; Rojas-Cortorreal et al., 2016]. 


\subsubsection{Cycle}

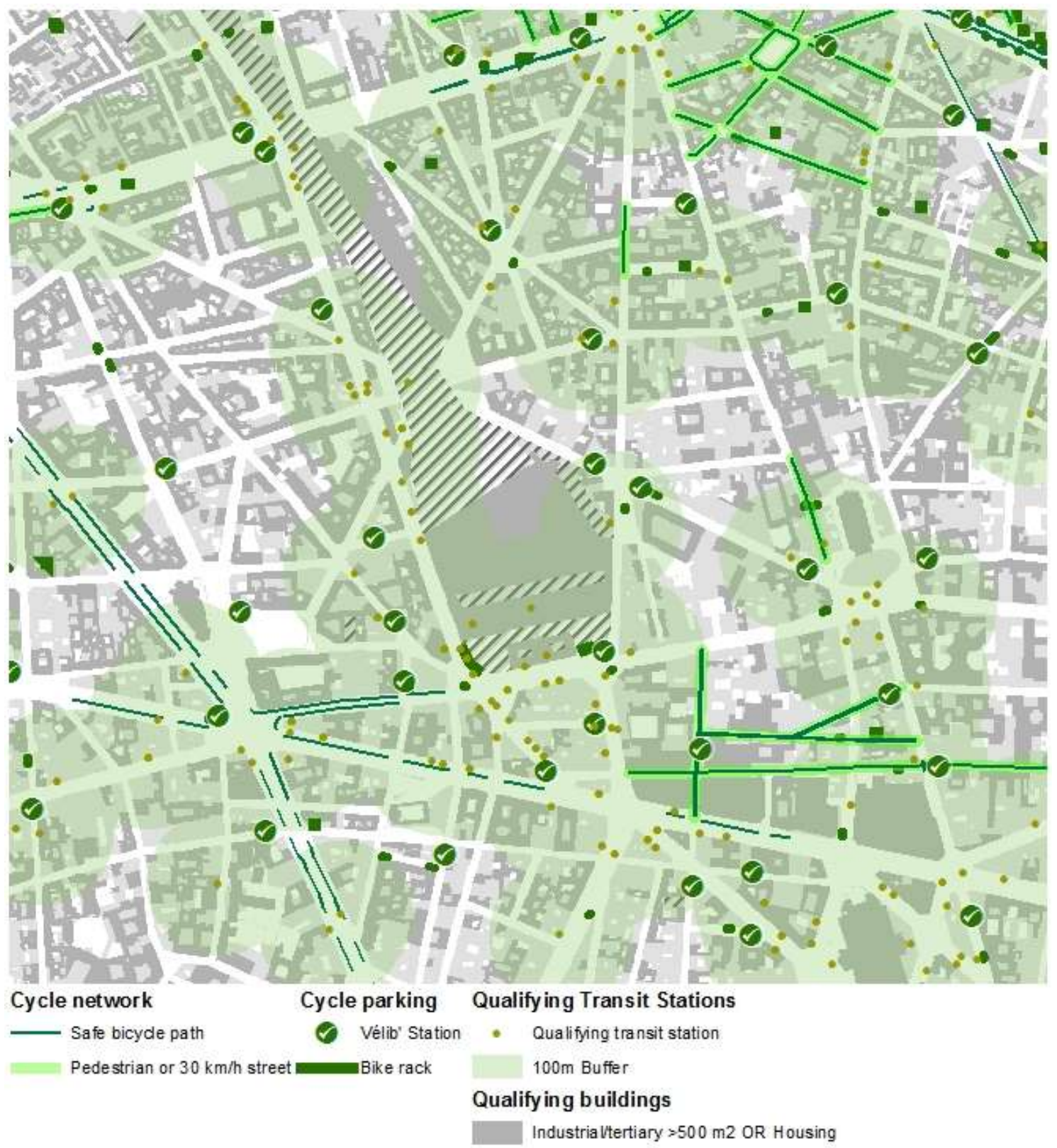

Figure 12: This figure displays three of the metrics of the cycle (2) principle, the cycle network (2.1), the cycle parking at transit stations (2.2) and the cycle parking at buildings (2.3).

In the case of the cycle principle and its three analyzed metrics, the graphical representation does not only show the uneven distribution but also the disconnection of networked elements. Regarding the Cycle network metric (2.1), the spatial disconnection of the "safe cycle paths" existent in the area shows the inexistence of a complete network and, therefore, prevents a feasible use of the bicycle as a transportation mode. The same quantity of "safe cycle paths" distributed forming a connected network in relation with cycle and transit stations, although still being scarce for the area, might bring more possibilities to use cycle for transportation. Consequently, the mapping of the path's spatial distribution provides an information useful to complement the evaluation of the area's cycling performance area.

In the case of cycle parking at transit stations (2.2) and cycle parking at buildings (2.3), the mapping of the phenomena distribution in the space also provides complementary information to the mean area's value. The observations that can be extracted from this case are similar to those 
of the Walk principle, regarding the importance of accounting for spatial distribution when analyzing a location based phenomenon. However, the trends might be less clear visually in this case. For analysis in need of precise conclusions in this issue, spatial statistics tools could be used to further analyze and visualize this distribution. In addition, the use of network analysis and service areas would be highly recommended instead of bird fly buffers if the focus is placed to walkable accessibility and service areas. 


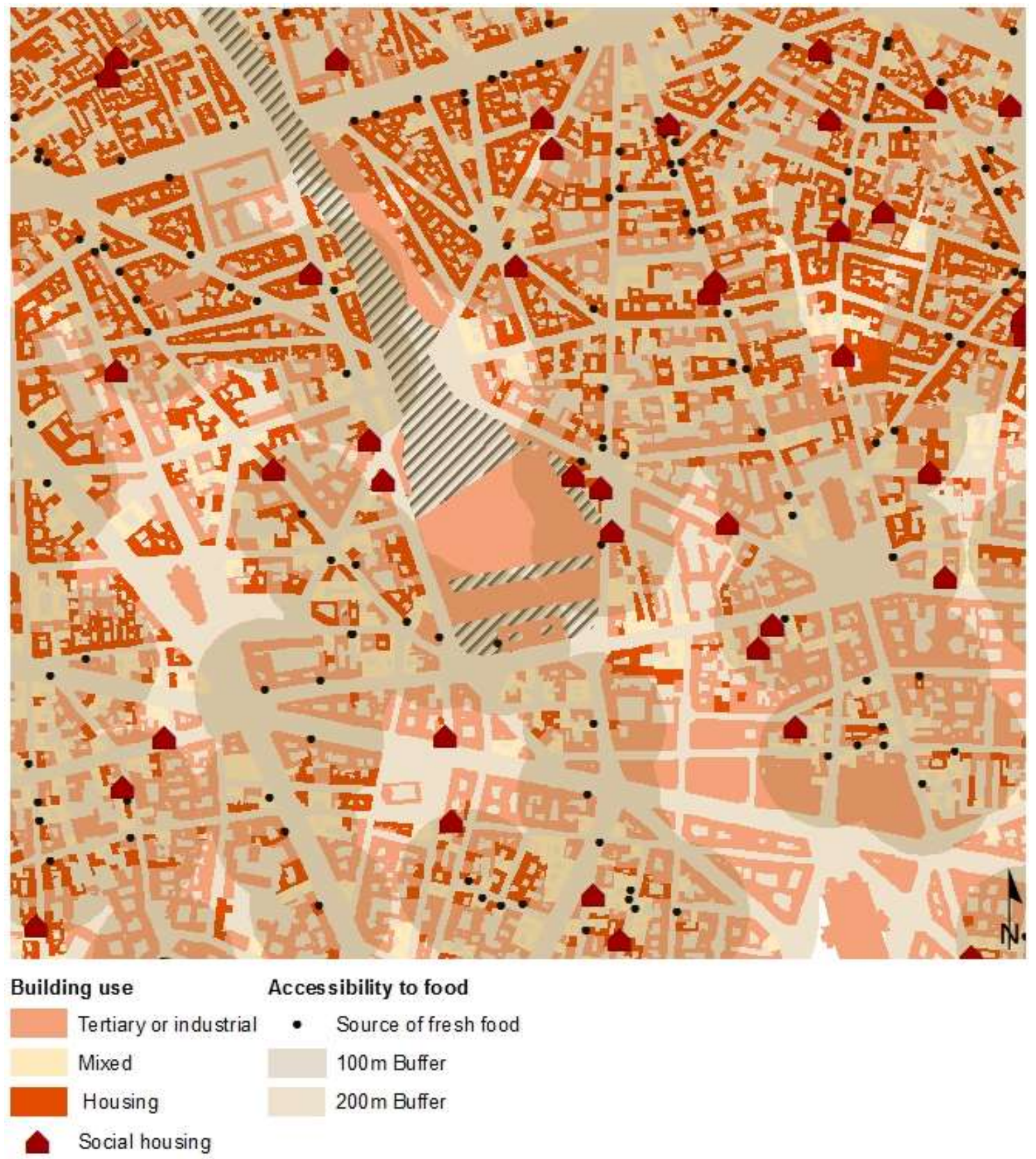

Figure 13: This figure displays the three metrics of the mix (5) principle, the complementary uses (5.1), the accessibility to food (5.2) and the affordable housing (5.1).

For the complementary uses metric (5.1), the GIS map (Figure 13) highlights a very clear divergence between the southern and northern parts of the area, divided by the horizontal line extended from the station's main façade. In the southern part, the tertiary and industrial uses are clearly dominant, while the northern part is constituted in great part by housing.

In the case of the accessibility to food metric (5.2), the map allows to identify that the locations with less accessibility to food are the area of the "Opéra Garnier" and the area around the "Église Saint-Agustin", two public buildings that, due to its use, have little need of fresh food. However, as in the case of the cycle parking at transit stations (2.2) and cycle parking at buildings (2.3) metrics, the use of network analysis would be highly recommended if the focus of the analysis was placed in walkable accessibility to certain facilities. 
Regarding the affordable housing metric (5.3), the opposite observation can be made. The few located social housing are homogenously distributed around the area. However, it can be noted that the sides of the "grand boulevards" are avoided, an interesting observation considering that these streets is where, in general, most highly valued housing are located. Nevertheless, the cartography contributes to verify the homogenous distribution of social housing. The same score could have been obtained by an enclosed area of concentrated social housing within the analyzed zone isolated from the surroundings. In this case, the social reality would be radically different, not ensuring a genuine diversity within the neighborhood.

The graphical representation of these principles allows for the identification of an irregular spatial distribution in all the cases. This irregularity can imply that some specific locations or cases might counterbalance the mean of the whole area.. Therefore, to only rely on the numerical value would not effectively convey the reality. Consequently, in order to obtain more accurate results, these outliners might be addressed specifically and analyzed apart from the general study. On the other hand, the irregularity might also be a consequence of zone-based diversity not connected with specifically located outliners but areas with different characteristics. In these case, the study could sub divide the area in meaningful zones in order to achieve more representative results. In addition, urban elements that constitute a network should not only be measured in quantity but also their interconnection needs to be taken into account. The cycle principle is especially clear in this case but other aspects of urban mobility follow similar principles, such as walkable paths, crosswalks or transit stations connection with their surroundings. Specific GIS tools could be useful to address these issues further, such as those within spatial statistics field [ref?] and network analysis [ref]. However, even if those methods would be implemented, it is important not to undermine the capacity of maps and graphical representation to clearly display geographical distribution and spatial relationships within the urban environment.

The aim to understand the city in its whole should not lead us to a simplification of the reality as a result of partial or incomplete analysis. Although standardization, organization and classification can be useful tools to grasp a complex environment, it is important to be aware of everything that is not being measured or even cannot be measured [Radović, 2013]. Admitting that the TOD Standard succeeds in providing a simple tool to analyze urban areas regarding their walkability characteristics, professionals involved in city planning and design should be aware of its limitation in describing the complexity and diversity of perspectives within the urban environment. Consequently, though the TOD Standard offers a first indication of urban environments quality regarding walkability issues, complementary and diverse studies are needed in order to reach a more complete vision.

\section{CONCLUSION}

Cities are complex systems where different interests, needs, habits, experiences, cultures and perspectives meet. The understanding of the diverse layers conforming their reality is key to be able to make decisions that affect their - and our - future. Moreover, a great range of professionals from diverse backgrounds and stakeholders with different interests meet in the field of city making. Consequently, investing in improving both our analysis and communication tools is essential to face nowadays urban challenges.

The evaluation of complex phenomena through average values, regardless of the graphical distribution can result in an analysis failing to meaningfully translate the urban scene. In urbanenvironment parameters analysis, considering other indicators than average values - or at least being aware of the limited representability of the latter - is necessary. Using spatial statistics tools can be useful to avoid undermining the importance of clustering and dispersion. However, the display of maps and their graphical analysis can also offer precious information. It not only allows 
the identification of outliners or distribution patterns of a given metric features, but also the understanding of its significance when overlaying it with other data layers of the urban space.

Different observations should be addressed regarding the current study. Firstly, the availability and type of data can influence the possibility of measuring the TOD standard through its scoring system, both the numerical and graphical analysis. Consequently, it should be acknowledged that different locations might have different possibilities of accessing data and the data might have been collected in different ways. This situation can highly influence the results obtained, threatening the reliability of a cross sectional comparison. In addition, the TOD Score often relies in the definition of areal units that, using vector based analysis, fall prey to the Modifiable Areal Unit Problem (MAUP), regardless the system to display the results, numerical or graphical. This problem should be addressed in all kind of urban evaluation scoring systems.

The current study has been limited to graphically represent recorded data through urban floor plans using GIS software. However, data can be collected and expressed in a great variety of ways [Radović, D., 2014a, 2014b]. In relation with graphical expression, section and visual perspective [Cullen, 1971] would be other methods useful to counterbalance the limitation of floor plans. Nevertheless, other communication systems, such as graphics, conceptual diagrams, text or media, might also be needed to avoid partial perspectives. In addition, data may be richer if coming from a great range of diverse sources, such as professional observations [Gehl, 2001], users' perspectives and raw data gathering.

Finally, in order to be able to make decisions regarding cities' future, a thorough analysis of the existing is needed and these studies should aim for completeness and accurate reflection of the complex reality. Even more important, the need for extracting meaningful conclusions should not blur the great range of uncollectible or unmeasurable information that conforms the sensibility of a place [Smithson et al., 2016] that, although impossible to quantify, is to be acknowledged.

\section{ACKNOWLEDGMENTS}

This work has been supported by the Spanish Ministry of Economy under project code: BIA201345597-R.

\section{REFERENCES}

\section{Publications}

- Ackerson, K. J. (2005). A GIS approach to evaluating streetscape and neighborhood walkability (Master's thesis). Retrieved from University of Oregon Libraries website: http://hdl.handle.net/1794/1286

- APUR (Atelier Parisien d'Urbanisme). (2002). Charte d'aménagement des espaces civilisés. Retrieved from http://www.apur.org/sites/default/files/documents/132.pdf.

- APUR (Atelier Parisien d'Urbanisme). (2007). Le quartier central des affaires de Paris. Retrieved from http://www.apur.org/sites/default/files/documents/APBROAPU386.pdf

- Calthorpe, P. (1993). The next American metropolis: Ecology, community and the American dream. New York, USA: Princeton Architectural Press.

- Jacobs, J. (1992). The death and life of great American cities (Rev. ed). New York, NY: Vintage Books.

- Carlton, I. (2009). Histories of transit-orientated development: Perspectives on the development of the TOD concept (Working Paper No. WP-2009-02). Retrieved from University of California, Berkeley, Institute of Urban and Regional Development website: https://iurd.berkeley.edu/wp/2009-02.pdf

- Cerin, E., Macfarlane, D. J., Ko, H. H., \& Chan, K. C. A. (2007). Measuring perceived neighbourhood walkability in Hong Kong. Cities, 24(3), 209-217. doi: 10.1016/j.cities.2006.12.002 
- Chanes, R. (2009). Deodendron. Árboles y arbustos de jardín en clima templado. Barcelona, Spain: Editorial Blume. ISBN: 9788480763684

- Cullen, G. (1971). The concise townscape. New York, USA: Princeton Architectural Press.

- Ewing, R. H. (2008). Characteristics, causes, and effects of sprawl: A literature review. In J. Marzluff et al. (Ed.), Urban Ecology: An International Perspective on the Interaction Between Humans and Nature (pp. 519-535). New York, USA: Springer US. doi: 10.1007/978-0-387-73412-5_34

- Ewing, R. H., Schmid, T., Killingsworth, R., Zlot, A., \& Raudenbush, S. (2003). Relationship between urban sprawl and physical activity, obesity, and morbidity. American Journal of Health Promotion, 18(1), 47-57.

- Friendly, M. (2002). Visions and re-visions of Charles Joseph Minard. Journal of Educational and Behavioral Statistics, 27(1), 31-51. doi: 10.3102/10769986027001031

- Gehl, J. (2011). Life between buildings: Using public space. Washington, USA: Island Press.

- Garcia-Nevado, E., Pages-Ramon, A., \& Coch, H. (2016). Solar access assessment in dense urban environments: the effect of intersections in an urban canyon. Energies, 9(10), 1-12. doi: 10.3390/en9100796

- ITDP (Institute for Transportation \& Development Policy). (2014). The TOD Standard v2.1. Retrieved 20.02.2017 from https://www.itdp.org/tod-standard/

- ITDP (Institute for Transportation \& Development Policy). (2017). The TOD Standard v3.0. Retrieved 30/06/2017 from https://www.itdp.org/tod-standard/

- Kaufmann, V. (2011). The individual motilities that make the city. In Rethinking the city: Urban dynamics and mobility (pp.65-84). Lausanne, Switzerland: EPFL Press.

- Kelly, C. E., Tight, M. R., Hodgson F. C., \& Page, M. W. (2011). A comparison of three methods for assessing the walkability of the pedestrian environment. Journal of Transport Geography, 19, 1500-1508. doi: $10.1016 /$ j.jtrangeo.2010.08.001

- Klosterman, R. 1994, Large-Scale Urban Models Retrospect and Prospect. Journal of the American Planning Association, Vol 60, No. 1, Winter 1994. Chicago, IL

- Le Parisien. (2010, October 1st). Feux tricolores: comment ça marche. Le Parisien, Île-de-France et Oise. Retrieved from http://www.leparisien.fr/beauvais-60000/feux-tricolores-comment-ca-marche-01-102010-1089936.php

- Leslie, E., Coffee, N., Frank, L., Owen, N., Bauman, A., \& Hugo, G. (2007). Walkability of local communities: Using geographic information systems to objectively assess relevant environmental attributes. Health \& Place, 13, 111-122. doi: 10.1016/j.healthplace.2005.11.001

- Leyden, K. (2003). Social capital and the built environment: The importance of walkable neighborhoods. American Journal of Public Health, 93(9), 1546-1551.

- Mairie de Paris. (2012). Plan de mise en accessibilité de la voirie et des espaces publics. Retrieved from http://www.vivre-paris.fr/docs_pdf/2012/2012-09_pave.pdf

- Mairie de Paris. (2017). J'aménage les parties communes: Locaux vélos et poussettes. Retrieved from https://api-site-cdn.paris.fr/images/79799.pdf

- Marquet, O. \& Miralles-Guasch, C. (2015). The Walkable city and the importance of the proximity environments for Barcelona's everyday mobility. Cities, 42 Part B, 258-266. doi: 10.1016/j.cities.2014.10.012

- Mezoued, A. (2016). L'in-adhérence spatiale du tramway d'Alger à l'échelle locale. In M. Srir (Ed.), Dynamiques urbaines à Alger : La (re)fabrication de la ville en questions (pp. 247-265). Paris, France: L'Harmattan.

- Montgomery, C. (2013). Happy city: Transforming our lives through urban design. New York, USA: Farrar, Straus and Giroux.

- NERA Economic Consulting. (2016). Étude des impacts socio-économiques des gares de SNCF Gares \& Connexions. Retrieved from http://www.nera.com/content/dam/nera/publications/2016

/160810\%20GC\%20impacts\%20socio-\%C3\%A9conomiques\%20\%20-\%20final\%20v2.pdf

- Newman, P. \& Kenworthy, J. (1999). Sustainability and cities: Overcoming automobile dependence. Washington, USA: Island Press.

- OMNIL (Observatoire de la mobilité en île-de-France). (2013). Enquête Globale Transport 2010-STIFOMNIL-DRIEA: La Ville de Paris. Retrieved from http://www.omnil.fr/IMG/pdf/egt2010_paris_bd2.pdf

- Pozueta, J., Lamíquiz, F. J., \& Porto, Matheus. (2009). La ciudad paseable. Madrid, Spain: Centro de Estudios y Experimentación de Obras Publicas.

- Pucher, J., \& Dijkstra, L. (2003). Promoting safe walking and cycling to improve public health: Lessons from The Netherlands and Germany. American Journal of Public Health, 93(9), 1509-1516.

- Radović, D (Ed.). (2013). Measuring the non-measurable Workbook 1: Intensities in ten cities. Fujisawa, Japan: IKI (International Keio Institute) + flick studio. 
- Radović, D. (2014a). Subjectivities in investigation of the urban: The scream, the shadow and the mirror. Fujisawa, Japan: IKI (International Keio Institute) + flick studio.

- Radović, D. (with Boontharm D.). (2014b). In the search of urban quality: 100 maps of Kuhonbutsugawa street, Jiyugaoka. Fujisawa, Japan: IKI (International Keio Institute) + flick studio.

- Robinson, A. H. (1967). The thematic maps of Charles Joseph Minard. Imago Mundi: The International Journal for the History of Cartography, 21(1), 95-108. doi: 10.1080/03085696708592302

- Rojas-Cortorreal, G., Roset, J., Navés, F., López-Ordóñez, C., and Crespo, I. (2016). El efecto del confort térmico producido por la especie arbórea almez en el espacio público. Architecture, City and Environment, 11(32), 187-202. doi: 10.5821/ace.11.32.4839.

- Santamaria, M., Martínez, P. (2016). La ideación del territorio de Barcelona a través de su representación. Architecture, City and Environment, 11(32), 171-186. doi: 10.5821/ace.11.32.4838

- Smithson, A., Smithson, P., and Risselada, M. (Ed.). (2016). The Space Between. Cologne, Germany: Walther Konig.

- Snow, J. (1855). On the mode of communication of cholera (2nd ed). London, England: John Churchill.

- Southworth, M. (2005). Designing the walkable city. Journal of Urban Planning and Development, 131(4), 246-257. doi: 10.1061/(ASCE)0733-9488(2005)131:4(246)

- Still, T. (2002, Winter). Transit-orientated development: Reshaping America's metropolitan landscape. On Common Ground, 3, 44-47.

- Sun, G., Zacharias J., Ma, B., \& Oreskovic, N. M. (2016). How do metro stations integrate with walking environments? Results from walking access within three types of built environment in Beijing. Cities, 56, 91-98. doi: 10.1016/j.cities.2016.03.001

- Sung, H., Oh, J.-T. (2011). Transit-oriented development in a high-density city: Identifying its association with transit ridership in Seoul, Korea. Cities, 28(1), 70-82. doi: 10.1016/j.cities.2010.09.004

- Parcerisa, J., Rubert de Ventós, M. (2001). Metro: Galàxies metropolitanes - Galaxias metropolitanas Metropolitan galaxies. Barcelona, Spain: Edicions UPC. ISBN 978-84-8301-655-8

- Ventura, F. X. (2016). Espacio y movilidad: la arquitectura de los desplazamientos. Madrid, Spain: Los Libros de la Catarata. ISBN (ARQIA): 978-84-617-6715-1 ISBN (CATARATA): 978-84-9097-251-9

\section{Websites}

- Autolib'. (2017). Autolib', Accueil. Retrieved 17.06.2017 from https://www.autolib.eu/fr/

- Esri (Environmental Systems Research Institute) Inc. (2017). ArcGIS Online Help. Retrieved 20.05.17 from http://doc.arcgis.com/en/arcgis-online/

INSEE (Institut National de la Statistique et des Études Economiques). Statistiques [Statistical datasets]. Retrieved 01/06/2017 from https://www.insee.fr/fr/statistiques

- Mairie de Paris/SOMUPI. (2010).Vélib', Accueil. Retrieved 17.06.2017 from www.velib.paris

- Open Data Paris. Les données [Geolocalised datasets]. Retrieved 12/05/2017 from https://opendata.paris.fr/explore/

- Open Data APUR (Atelier Parisien d'URbanisme). Toutes les données [Geolocalised datasets]. Retrieved 12.05.2017 from http://opendata.apur.org/

- Open Data RATP (Régie Autonome des Transports Parisiens). Les données [Geolocalised datasets]. Retrieved 12.05.2017 from https://data.ratp.fr/explore/

- PHAC (Public Health Agency of Canada). (2014). Qu'est-ce que le transport actif? Retrieved 05.06.17 from http://www.phac-aspc.gc.ca/hp-ps/hl-mvs/pa-ap/at-ta-fra.php

- SNCF (Société Nationale des Chemins de Fer français), SNCF Gares \& Connexions. Votre Gare : Paris Saint-Lazare, Histoire de la Gare. (2015). Retrieved 25.05.17 from https://www.garessncf.com/fr/gare/frpsl/paris-saint-lazare/actualite/10151/histoire-gare/

- SNCF Open Data. (2015). Fréquentation en gares [Dataset]. Retrieved 12.05.2017 from https://ressources.data.sncf.com/explore/dataset/frequentationgares/table/?q=Paris\&sort=voyageurs_2014

- Volusia County, Geographic information services. (2014). Buffer Analysis. Retrieved 20.05.17 from https://www.volusia.org/services/business-services/information-technology/geographic-informationservices/geographic-spatial-analysis/buffer-analysis.stml

\section{Software}

- ArcGIS for Desktop (Version 10.3.1) [Computer software]. Redlands, USA: Esri (Environmental Systems Research Institute). 